University of New Hampshire

University of New Hampshire Scholars' Repository

Languages, Literatures, and Cultures

Scholarship

Languages, Literatures, and Cultures

3-1-2012

\title{
Homophobic slurs and public apologies: the discursive struggle over fag/maricón in public discourse
}

Holly R. Cashman

University of New Hampshire, Durham, holly.cashman@unh.edu

Follow this and additional works at: https://scholars.unh.edu/lang_facpub

\section{Comments}

This is an article published by De Gruyter in Multilingua in 2012, available online: https://dx.doi.org/10.1515/

mult.2012.003

\section{Recommended Citation}

Cashman, Holly R. 2012. Homophobic slurs and public apologies: the discursive struggle over fag/ maricón in public discourse. Multilingua 31(1): 55-81.

This Article is brought to you for free and open access by the Languages, Literatures, and Cultures at University of New Hampshire Scholars' Repository. It has been accepted for inclusion in Languages, Literatures, and Cultures Scholarship by an authorized administrator of University of New Hampshire Scholars' Repository. For more information, please contact Scholarly.Communication@unh.edu. 


\title{
Homophobic slurs and public apologies: The discursive struggle over fag/maricón in public discourse*
}

\author{
Holly R. Cashman
}

\begin{abstract}
A handful of recent incidents hints at an ideological struggle over the use of the English word fag(got) and the Spanish word maricon in public discourse. This article examines the discursive and ideological struggle over the terms through the comparison of two cases in which Spanish/English bilingual Latinos in the U.S. use what might be considered homophobic slurs in public discourse in two distinct contexts - an informal, off-record sports-related press conference and a radio talk show political interview. The three main aims of the article are to examine and compare the content and context of the two public apologies, to examine the discursive and ideological struggle over the appropriateness of fag/ maricón in public discourse through the evaluation of their use, and to contextualize the two case studies within the research on the construction of homophobia in discourse.
\end{abstract}

Keywords: apologies, homophobia, discursive struggle, bilingualism, U. S. Latino

\section{Introduction}

In the first decade of the new millennium, a wave of incidents and public apologies (as well as public non-apologies) revolved around the use of the word fag in public discourse, in the arenas of politics, sports, and entertainment. Rapper Eminem was criticized by the Gay and Lesbian Alliance Against Defamation (GLAAD) for his use of homophobic slurs including 'fag(got)' in 2000. Right-wing political commentator Ann Coulter famously used the word 'fag(got)' to refer to Democratic politicians including Bill Clinton, Al Gore, and John Edwards. Actor Isaiah Washington, then star of the hit television drama Grey's Anatomy was accused of privately calling his cast mate T. R. Knight a faggot 
in an altercation with another cast member on the set in October 2006, and then used the word again at a televised award ceremony in January 2007 while publicly denying having said it in the first instance. In the world of sports, the Olympic gold medal winning Australian swimmer Stephanie Rice drew sharp criticism in September 2010 for her use of faggots in a tweet. This handful of recent examples hints at an ideological struggle over the use of $f a g(g o t)$ in public discourse.

Similarly, maricón in public discourse in Spanish has been the object of some controversy. Most recently, for example, a Chilean government campaign against violence against women by an entity called SERNAM (Servicio Nacional de la Mujer) used the slogan Maricón es el que maltrata a una mujer ['Faggot is he that beats a woman'] in a publicity campaign that features posters, t-shirts and televised public service announcements featuring various men, from actor Jorge Zabaleta to football referee Pablo Pozo and gay photographer and television host Jordi Castell. The publicity campaign provoked an international reaction, with some groups demanding that it be discontinued, while others, including El Movimiento de Integración y Liberación Homosexual, a Chilean gay and lesbian group, supporting the campaign (El Comercio 2010). In 1997, the Mexican punk rock band Molotov released an album including the song 'Puto', with lyrics that included a number of terms that have been considered homophobic slurs including the title puto, as well as marica, joto, and maricón. Most notably, the song's lyrics included the following phrase, a play on the lyrics of a traditional children's song: amo matón/matarile al maricón/¿y qué quiere ese hijo de puta?/quiere llorar quiere llorar ['love the bully (killer)/kill the faggot/and what does this son of a bitch want?/he wants to cry/wants to cry']. The band was protested during their European tour in 1998 and a Basque/Euskadi group supporting rights of lesbians and gay men demanded that the album be seized because of its flagrant violation of the penal code, specifically a section prohibiting hate speech (Cubillo 1998).

This article examines the discursive and ideological struggle over the terms fag in English and maricón in Spanish through the comparison of two cases in which Spanish/English bilingual Latinos in the U.S. use these terms that might be considered homophobic slurs in public discourse in two distinct contexts - an informal, 'off-record' sportsrelated press conference and a radio talk show political interview. The three main aims of the article are the following: (1) to examine and compare the content and context of the two public apologies, (2) to examine the discursive and ideological struggle over the appropriateness of fag/maricón in public discourse through the evaluation of their use in the two incidents, and (3) to contextualize the struggle over fag 
and maricón in the two case studies within the research on the construction of homophobia and masculinities. In the cases compared here, conceptualizations of ethnicity and masculinities interact in interesting ways that point toward diverging stances on heterosexism/homophobia and Latino masculinities in the U.S.

\section{Review of the literature}

\subsection{Discursive struggle}

The use of fag or maricón, when deployed as an insult or intentional face attack in interaction might be seen as an example of linguistic impoliteness. In some recent research, impoliteness has been examined as merely one section of a broader spectrum of behavior, known as relational work through which participants negotiate social relationships in interaction (Watts 2003; Locher 2004; Locher \& Watts 2005). This approach emphasizes that categories such as 'polite' or 'impolite' are not neatly delimited, are not universal, and are discursively constructed (Locher \& Watts 2005). Evaluation and interpretation of others' behavior as impolite, rude, inappropriate, or offensive takes place in interaction and in a given context, which means that there are no inherently polite or impolite linguistic structures (Watts 2003). Rather than encapsulate inherently understood linguistic structures, terms such as rude or polite are subject to discursive struggle (Watts 2003), or dispute and negotiation over their evaluation by participants in interaction, and are discursively variable (Watts 2008), in that they depend on participants' completion of emergent meaning. In the case of public discourse, this discursive struggle need not necessarily take place in the course of one interaction, and may indeed take place over the course of a public apology incident, with the intervention of crisis management and public relations strategies and through the involvement of individuals and organizations alike. The discursive struggle over offensive speech in the public arena becomes an ideological struggle in which divergent and opposing stances with regard to what may be seen as slurs are related to larger issues of heterosexism and masculinities, ethnicity, and marginalization.

The present analysis is informed by a discursive approach, relying on concepts including discursive struggle, appropriateness, and discursive and social context as it seeks to understand the emergence of a conceptualization for the appropriateness of what might be considered homophobic public discourse where English and Spanish overlap among bilingual Latinas/os ${ }^{1}$ in the U.S. 


\subsection{Slurs}

The notion that the meaning of linguistic structures is discursively variable is, in some ways, at odds with the concept of the racial, ethnic, or sexual identity slur, which tends to bracket off certain words as universally and unequivocally inappropriate and offensive. A slur, in other words, is a word used to refer to a member or members of a protected class in a disparaging or offensive manner (Henderson 2003). Despite this definition, which suggests a static or stable meaning, slurs are often the object of ideological struggle, with in-group and out-group constituencies and with public discourse and print media endorsing different stances with regard to their use, as King \& Clarke (2002) point out in relation to the term Newfie in Canada. Words are not innately or objectively derogatory or offensive, slurs or insults. These attributes are the result of the accumulated evaluation of speakers involved in a discursive struggle over appropriateness and inappropriateness and engaged in an ideological struggle over marginalization and inclusion. Louw (1993: 157) describes this accumulated evaluation of meaning using the term semantic prosody, which he defines as 'a consistent aura of meaning with which a form is imbued', In Louw's case, however, the imbuing of meaning is carried out by a coloring of one term due to its habitual association with certain collocates, either positive or negative. In the case of slurs, however, it is the sociohistorical context of their use as instruments of discrimination and marginalization based on the race, ethnicity, or, in this case, sexual identity of their target that imbue the terms with meaning. This meaning, however, is to some degree elastic as users of language both rely on the meaning the words bring into an interaction while they negotiate the meaning, interpretation, and power of words within an interaction. The interpretation of words that may be considered slurs varies depending on a variety of factors including the speaker's identity, the speaker's intention, the hearer's identity, and the context, among others.

\subsection{Apologies}

Goffman (1971: 113) asserts that '[a]n apology is a gesture through which an individual splits himself into two parts, the part that is guilty of an offense and the part that dissociates himself from the delict and affirms a belief in the offended rule'. Mbaye (2005) explains that an apology is a complex, nuanced speech act with several crucial factors, including the expression of mortification, the expression of remorse, the speaker's sincerity, and the speaker's promise to refrain from future harm of the wronged party. 
The linguistic realization of the apology speech act can take many forms and can vary considerably. In the field of linguistic politeness, models of speech acts, often based on prototypical or ideal examples, have been developed. Based on Cohen \& Olshtain (1981), Olshtain \& Cohen (1983), and Blum-Kulka et al. (1989), Suszczynska (1999: 1056) proposes a model for the speech act 'apology' that includes an Illocutionary Force Indicating Device (IFID) such as an expression of regret ('I'm sorry') or a request for forgiveness ('Pardon me'), an explanation or account of mitigating circumstances ('I didn't know ...'), a taking of responsibility ('It's my fault'), an expression of concern for the hearer ('I hope I didn't hurt you'), an offer of repair ('I'll pay for the damages'), and a promise of forbearance ('It won't happen again').

Mills (2003: 222) asserts that 'apologies cannot be considered to be a formal linguistic entity ... since they can be made using a wide range of different linguistics strategies'. Recognizing this range of strategies, but also noting that not all strategies are equally preferred, Jeffries (2007) attempts to describe the range of features and strategies of apologies in English, including prototypical, alternative, and least prototypical realizations; these are summarized in table 1 :

Table 1. Features of apologies in English, adapted from Jeffries (2007: 66).

\begin{tabular}{|c|c|c|c|}
\hline Feature & Prototype & Alternative & Least prototypical \\
\hline IFID & $\begin{array}{l}\text { Expression of } \\
\text { regret }\end{array}$ & Performative & $\begin{array}{l}\text { Request for } \\
\text { forgiveness }\end{array}$ \\
\hline Tense/asp. & Simple present & Present progressive & Past/future/modal \\
\hline Person & 1st singular & 1st plural & $3^{\text {rd }}$ \\
\hline Following text & Concern/reparation & $\begin{array}{l}\text { Explanation/respon- } \\
\text { sibility }\end{array}$ & Nothing \\
\hline Level of 'wrong' & Main & Supplementary & Small, irrelevant \\
\hline Timing of 'wrong' & Recent past & Distant past & Present, future \\
\hline Sincerity & Sincere & Doing sincerity & Openly cynical \\
\hline Addressee & Wronged & Symbolic of wronged & $3^{\text {rd }}$ party/anyone \\
\hline Responsibility & Directly & Symbolically & Not responsible \\
\hline Impetus & Unsolicited & Solicited & Demanded \\
\hline Best interests & Agreed & Not agreed & \\
\hline Equality & Equal & Unequal & \\
\hline Intention & Intended & Ambivalent & $\begin{array}{l}\text { Unintended/not } \\
\text { intended }\end{array}$ \\
\hline Acceptable & Accepted & Questioned & Rejected \\
\hline
\end{tabular}

Jeffries (2007: 67) notes that 'an apology can take place over a period of time, and gradually work towards the centre of the prototype by adding more and more prototypical features'.

Public apologies differ from apologies in ordinary conversational interaction, as explained by Harris, Grainger \& Mullany (2006: 720- 
723). First, as the term suggests, public apologies take place in the public domain, and they tend to be very highly mediated. Public apologies are also distinguished by the entity that performs the speech act. Rather than private individuals, performers of public apologies may be representatives of nation states or other political entities, businesses or organizations, public figures (politicians, celebrities). Furthermore, public apologies are triggered by controversy, and they, in turn, may trigger more controversy. The inclusion of an explicit IFID and acceptance of responsibility or blame is often crucial for the success of the public apology. Finally, it is rare for the response to the public apology to be explicit absolution from the aggrieved because of substantial difference in power. For Hearit (2005) the apology is a tool of managing public crisis and restoring image; he describes the five stages of a public apology incident. In the first stage, the sociocultural order is transgressed, which is followed in the second stage by an accusation of wrong-doing. The third stage is a social legitimation crisis, which is followed by a public apology, stage four. The public apology, if felicitous, would be followed by the fifth stage of forgiveness in which the sociocultural order is re-established.

\section{The two cases}

\subsection{Case 1: Ozzie Guillén, baseball manager}

Oswaldo 'Ozzie' Guillén ${ }^{2}$ is the World Series winning Major League Baseball manager of the Chicago White Sox. A native of Venezuela, Guillén is a former professional baseball player, who played shortstop, chiefly for the Chicago White Sox, from 1980 to 2000. Guillén is known, and beloved by many, for being outspoken and frank. The saying 'Ozzie being Ozzie' was coined and is used as a way to dismiss or forgive some of his behavior and comments judged to be outside the bounds of acceptability. An example of the 'Ozzie being Ozzie' philosophy is summed up in a column by Chicago Sun-Times sports writer Neil Hayes:

He's always in the middle of some kind of controversy. That kind of constant drama wears people out, especially when viewed from afar ... Not that he cares what anybody thinks. He's loud, brutally honest, politically incorrect on occasion and always profane. He's not going to change.

(Hayes 2009: para. 4-5)

In addition to being known for 'being Ozzie', Guillén is also known for having a pronounced non-native Spanish accent when he speaks Eng- 
lish. In a (2006) article, a sportswriter lampoons Guillén's pronunciation, which he refers to as 'warped English,' transcribing conversations with him in a pejorative eye dialect ${ }^{3}$ and joking with various assistant managers, players, and his boss about how hard it is to understand him. Reilly, however, insists that

I'm not making fun of him! I'm just saying I wouldn't want to be the beat guy for the Chicago Tribune trying to understand him. Or the rookie just in from Shreveport. Or his accountant. Because even though the man has been working in this country for 26 years, his accent is thicker than Chita Rivera's makeup.

(Reilly 2006: 1)

Alexander (2006) discusses the pattern of stereotyping Latino baseball players as hot-tempered, as selfish, or as goofy sidekicks; both the hottempered and the goofy frames are juxtaposed in Reilly's portrait of Guillén. A connection between Guillén's English proficiency and his reputation of being hot-tempered is made by White Sox third base coach Joey Cora, who is quoted as saying, 'If Ozzie knew English better, he wouldn't be Ozzie. He tells you what's in his heart, not what you want to hear. Maybe if his English were better, he wouldn't do that. Maybe he'd tiptoe around the truth more' (Reilly 2006: 3). The question of 'Ozzie being Ozzie', his temper, and his English proficiency would all come into play in a June 2006 conflict with Jay Mariotti, then a sports columnist for the Chicago Sun-Times newspaper. ${ }^{4}$

On Tuesday, 20 June 2006, during a clubhouse question and answer session with the media, a reporter asked Guillén what he thought about Jay Mariotti, who had recently written a column critical of Guillén. Guillén's response was published widely, albeit with various elements censored (Zwicky 2006): 'What a piece of shit he is. Fucking fag.' This, according to Hearit's (2005) description of the public apology incident, represents the first step, or transgression of the sociocultural order. The following step, accusation of wrong-doing followed quickly in the form of a newspaper editorial. One reporter present at the question and answer session, Greg Couch, also of the Chicago Sun-Times, made the decision to publish an editorial about Guillén's use of the word fag:

The issue is that Guillen said the wrong thing, and he does it often and it never sticks to him. That's just Ozzie, we hear. And the Sox tend to chuckle about this stuff, as if we can just forgive him. Why? Because English is his second language? Not good enough. Last year in New York, he referred to someone as homosexual and a child molester, equating the two. He took some heat for that one, briefly. So he should have known. Guillen is not dumb. Let's not insult him. 
He knows what he's saying, and he certainly knows that it's not acceptable. He has been in this country for a quarter of a century. This offseason, I went to his swearing-in as a U.S. citizen. He was wrong. And he needs to apologize. And he needs to be suspended.

(Couch 2006)

In the editorial, Couch explicitly evaluates Guillén's use of fag as beyond the bounds of appropriate language. Couch articulates several arguments invalidating hypothetical explanations and accounts, such as a lack of English proficiency, ignorance, unawareness of norms. In countering these hypothetical claims, Couch claims one particularly interesting stance vis-à-vis intercultural pragmatics and awareness: Guillén's status as a U.S. citizen, in addition to over 25 years of living and working in the U.S., invalidates any potential claim of unawareness or misunderstanding of the acceptability of fag in public discourse. This claim suggests two things: first, that the norms are static and universal; second, that all U.S. citizens necessarily share a set of norms regarding the acceptability of slurs.

Major League Baseball, the Chicago White Sox, and the media reacted promptly to the incident, initiating stage three of Hearit's public apology incident - a social legitimation crisis. Bud Selig, Commissioner of Major League Baseball, issued a statement including the following:

On Tuesday night, Ozzie Guillen used language that is offensive and completely unacceptable. Baseball is a social institution with responsibility to set appropriate tone and example. Conduct or language that reflects otherwise will not be tolerated. The use of slurs embarrasses the individual, the club and the game.

(ESPN 2006)

Selig categorizes the word fag as a slur and characterizes it as 'offensive' and 'unacceptable'. Like Couch, Selig indicates that the use of the word fag is not appropriate in the context of professional baseball. Rather than say anything about the target of the slur, Jay Mariotti, Selig's statement focuses on the organization's stance with regard to language it deems inappropriate. In his statement, Vice President for Communications for the Chicago White Sox, Scott Reifert takes a markedly different stance:

I don't think in that case that Ozzie was trying to disparage a group. That said, it certainly is a poor word choice. It's insensitive. It's not something we would condone, not something the White Sox would stand for.

(Sports Business Daily 2006) 
While the Commissioner's statement condemns Guillén and upholds the league, Reifert attempts to simultaneously defend Guillén while condemning his behavior and distancing the Chicago White Sox from his remarks. To accomplish this, Reifert uses several hedges and mitigations, which contrast markedly from the directness of Couch's editorial and Selig's statement. Most notably, Seifert employs the conditional ('would condone', 'would stand for') in contrast to Selig's future tense ('will not be tolerated'). Seifert's lexical choices also diverge from those of the Commissioner. While the former statement describes fag as 'offensive' and 'completely unacceptable', the latter downgrades this evaluation to 'insensitive' and 'a poor word choice'. Finally, Reifert defends Guillén by raising the question of intention, a central element in the definition of hate speech (Matsuda et al. 1993) as well as definitions of impoliteness (Culpeper 1996; Bousfield 2008). Although Reifert hedges his assertion ('I don't think'), he asserts that Guillén's use of fag was not an intentional attack. In sum, Reifert condones the insulting or taunting of a sportswriter, while emphasizing that the disparagement of an oppressed group is not acceptable and weakening the status of fag to something less than a slur due to lack of intention.

Following the typical structure of the public apology incident, Guillén apologized the next day, Hearit's stage four. Rather than issue a prepared statement or hold a formal press conference which is almost de rigueur in contemporary crisis management (cf. Hearit 2005), Guillén apologized in the same environment in which he made the initial comment - an informal, clubhouse pre-game Q\&A session with reporters. What follows it the transcript of a partial recording of the session (4:45 min.) in which Guillén $(\mathrm{G})$ and reporters $(\mathrm{R})$ interact: $^{5}$

$01 \mathrm{G}$ : I mean I'm not going to back up on Jay he's a piece of [edited] ((laughs)) you

02 know what I mean? and what I said about uh about the name what the word I

03 used I should have said something different I think a lot of people (was) hurt

04 feelings I don't mean it like that way but is Jay (another part)? yeah I think Jay I

05 made more money you know I think I make this guy make a lot of money

06 and be famous you know not because (before) Ozzie Guillén nobody knows him

07 you know what I mean? but uh if I hurt anybody by what I said by the name you

08 know by calling him? I apologize but I wasn't talking about those people I was

09 talking about him and strictly to him uh besides that to me he's still he's not a

10 man uh I think he's still uh he's bad for this city he never done anything good

11 for this city and I'm the I think I'm the only one I'm the only one to to to get him

12 but you know I just I'm not going to I don't waste my time talking about Jay you

13 know Jay is a piece of [edited] and if he wants to know he should be here talking

14 to me right now if he's man enough he should be here with you guys

15 R1: Ozzie what do you think about the people who say you should be suspended?

$16 \mathrm{G}$ : should I be suspended because I call one guy that? you know I I I I'll say you 
40 R3:

$41 \mathrm{G}$ :

66 R5: did you think that you were off the record at the time? 67 G: I was I (was talking) you know if- if- off the record thing about talking about Jay 68

know I call him like that because I should have used another word and you know you gonna be suspended because you you don't like one guy and you say and that (one determination or should) but you know I mean just they they can do whatever they want but I'm not gonna back it up I'm gonna say I will apologize to the people (1.0) I offended eh because I should have said used another word but besides that I'm still waiting for Jay

: did White Sox management uh talk to you about

mmm not really I they know you know I talked to to Jerry I talked to Kenny um I to Kenny more about about uh Brian Anderson besides that Kenny's out (if he says I) have to say something to Jou know what I mean nobody likes that man here you know I mean but I don't care what he thinks about me but I think Jerry you know talked to me said you know I should talk some say something about the word I used you know what I mean and he will back me up and and I (have a) comment about Jay I say you better (pay attention you better wise up about your lying) he did he doesn't have enough guts to show up why why is he so af- so afraid to show up to the ballpark? you know what I mean when you're afraid to do do something you feel guilty about something then tell him we'll bring a cab.

\section{((laughs))}

Ill take a limo to where he lives bring it to the ballpark and have a conversation with us but you know but that's the way he is that's the way he is he's a garbage and he's always been a garbage and he always will will be a garbage

do you do you think this is giving him a a lot of publicity?

yeah ((laughs))

he should thank me because now he's he's more famous than than you know what he was you know but that's why I don't want to him make more famous Jay I you know he's a garbage still a garbage gonna die as a garbage period

: Ozzie given that there may have been some cultural issues involved in your use of the word that you used, would you be open to sort of some sensitivity training and would you go if if the organization asked you to?

about what? words are offensive to (inaudible)

well you know it's it's it's you know I've been here for twenty years but people have to know I'm I grew up in a different country it's not I mean that's no excuse I called the guy that name but if if if (that thing)? no because that's the way I grow up that's the way I I learned it this language and (I have no excuse) I have here I have enough years here to know you (can't) use so many words in the states you know I mean that's not an excuse and I think I no was calling people that way I was calling him that I don't mean people I've got friends in that community ((laughs)) I mean you think it's funny I got I got a couple of phone calls this morning about the guy that gives me haircuts my my wife's best friend and they start laughing

but it's just you know I mean I just ((laughs)) I just called Jay like that I wish I can see him face to face to call him face to face but he's only in the bars he's 
69 you know this guy is so silly he just went to national TV and said how these

70 people call me worse (they don't know) about me you know what I mean that's

71 that's that's idiot but you know I mean just you know just make Jay go

72 somewhere and just move on and just continue but I'm not gonna back it up on

73 Jay I never will

74 R6: do you think a lot of this is because you're in the spotlight because of winning or

75 do you think it's kind of a personal thing?

$76 \mathrm{G}$ : I to me it's personal now to me it's personal this guy never writes anything

77 positive about the city in this city he's always negative and he makes a lot of

78 money doing that and now now it's personal now it's personal and I will take it

79 personally

Using Jeffries' (2007) framework of prototypical, alternative, and least prototypical realizations of apology features, much of what might be considered Guillén's apology diverged from the prototypical. One general question regarding the analysis of the apology is the question of to whom it is addressed. While this issue is accounted for specifically in the feature 'addressee' below, it obviously bleeds into the other features as well. The main question is whether the aggrieved party is Jay Mariotti, whom Guillén called a 'piece of shit' and 'fucking fag', or the members of the LGBT community, ${ }^{6}$ whose objection to the use of the term fag fueled the demanded for an apology, or, to some extent, both. Guillén emphasizes on two occasions during his apology that not only has Mariotti not been wronged by Guillén, but that he has actually benefited from the situation. In the analysis that follows, Guillén's apology will be considered as having two separate addressees: Mariotti and the LGBT community.

In the Jeffries model, the first three features focus on the IFID: the type of IFID, the tense and the person. The prototypical IFID, according to Jeffries, is an expression of regret, such as 'I'm sorry'. Guillén, instead, used the alternative, a performative, twice: 'I apologize' (line 8), 'I will apologize to the people I offended' (line 20-21). One of these IFIDs uses the simple present, which Jeffries identifies as the prototypical, the other uses the future, which is one of the least prototypical options. Both IFIDs use the first person singular, the prototypical person for the IFID. Guillén's two IFIDs are addressed to the LGBT community; there are no apology IFIDs in Guillén's apology that are addressed to Mariotti. Instead, Guillén repeatedly states that he will not let up on his attacks on Mariotti: 'I'm not going to back up on Jay' (line 1), 'I'm not going to back it up' (line 20), and 'I'm not going to back it up on Jay I never will' (lines 70-71).

The next feature in Jeffries' model focuses on the textual context of the IFID in the apology, specifically the following text, or what has been referred to as supporting moves (Blum Kulka et al. 1989). Following the IFID, Guillén employs both the prototypical feature, which 
would be to demonstrate concern or offer reparation, and the alternative strategies, i.e., he takes responsibility and offers explanations. While Guillén does not offer reparation, he does show at least a small measure of concern: 'I think a lot of people (was) hurt feelings' (lines $3-4)$. The taking of responsibility is expressed several times: 'the word I used I should have said something different' (lines 2-3), 'I should have used another word' (line 17), and 'I should have said used another word' (line 21). His explanations are three-fold: first, he asserts that members of the LGBT community were not his intended addressee or the target of his remarks, 'I wasn't talking about those people' (line 8) and 'I don't mean people' (line 58); second, he argues that as a nonnative speaker of English he selected the wrong word, 'people have to know I'm I grew up in a different country' (lines 52-53) and 'that's the way I grow up that's the way I learn this language' (lines 54-55); and finally he affirms indirectly that he is not homophobic, 'I've got friends in that community' (lines 58-59). Although he makes three types of explanations, Guillén also twice mitigates the force of his explanations with the following statements: 'I have no excuse' (line 55) and 'that's not an excuse' (line 57). In contrast to Mariotti, Guillén not only chooses the least prototypical following text (i.e., nothing); he also engages in several aggravated face attacks: first, Guillén insults Mariotti, 'he's a piece of [edited]' (line 1), 'Jay is a piece of [edited]' (line 13), 'this guy is so silly' (line 69), 'idiot' (line 71), 'he's a garbage he's always been a garbage he always will be a garbage' (lines 38-39), and 'he's a garbage still a garbage gonna die as a garbage period' (line 45); second, Guillén insists that Mariotti is a traitor to Chicago, 'he's still uh he's bad for this city he never done anything good for this city' (lines 10-11) and 'this guy never writes anything positive about the city in this city he's always negative' (lines 76-77); finally, and most interestingly for the present analysis, Guillén questions Mariotti's manhood, 'to me he's still not a man' (lines 9-10), 'he doesn't have enough guts to show up' (line 32-33), and 'if he's man enough he should be here with you guys' (line 14).

Five additional features in Jeffries' model concern the broader context of the apology: level, timing, sincerity, addressee, and impetus. Regarding the LGBT community, the level of the apology is main, which is the prototypical feature. In other words, the apology addresses that which is 'the most significant wrong between the speaker and the wronged person' (Jeffries 2007: 65). The timing of the apology, the day following the alleged wrong, is also prototypical, although the impetus is alternative at least and perhaps even least prototypical. As Guillén references explicitly that 'Jerry you know talked to me said you know I should talk some say something about the word I used' (lines 29- 
30). Given the context of the reporter's question, Jerry is a member of the White Sox organization, so Guillén indicates that he is apologizing in response to a suggestion from his employer. Whether this would be considered a demand (least prototypical) or a solicitation (alternative), it is clear that the impetus is external. With regard to the addressee, Guillén strays from the prototypical feature in that he does not directly apologize to the members of the LGBT community or through leaders of LGBT organizations, but rather through the conduit of the sports writers whom he is addressing directly. The sincerity of Guillén's apology to the LGBT community is open to debate, and will be addressed below. With regard to Mariotti, the features of level, timing, impetus, addressee, and sincerity are moot since there is no apology.

Finally, the remaining features of best interests, equality, intention, and outcome (accepted or rejected) relate to features well beyond the text of the apology itself but they are integral to the success of the apology. Vis-à-vis the LGBT community, Guillén's intention seems clearly to apologize, and it would seem that in a general sense he does not in any way dispute the best interests of the wronged party. In the sense that he is a widely celebrated sports figure, it could be argued that Guillén enjoys a higher status or more power than the LGBT community, thus equality would be seen as unequal, a non-prototypical feature. With regard to the last feature, whether the apology is acceptable, the evaluations of the public, as well as the outcome of the apology, are explored below. In the case of Mariotti, Guillén clearly does not agree with his best interests, their position is unequal in that there is a difference of status and power that precedes the alleged wrongdoing and Guillén's intention is to further insult rather than to apologize to Mariotti. The outcome is that Mariotti does not feel that he has been apologized to, which he comments on publicly in a variety of forums.

The discursive struggle over the public use of fag that followed Guillén's transgression continued in the mainstream sports media (print, radio, and television) and also on-line in blogs and discussion boards. While it would be impossible to include an analysis of the full spectrum of this discourse, it would be instructive to examine the evaluation of Guillén's apology by specific targeted groups, including more specific segments of the population, such as that those represented by Out Sports (outsports.com), an LGBT sports blog. The Out Sports analysis of the incident argues the following (emphasis original):

This is not the first time Guillen has used anti-gay language (see below), and again the White Sox organization is trying to cover for him ... Greg Couch, Sun-Times columnist, ripped into Guillen and said he needs to be suspended. He told Guillen what he was going 
to write: Guillen said that in Venezuela, that word is not a reference to a person's sexuality, but to his courage. He said he was saying that Mariotti is 'not man enough to meet me and talk about [things before writing]'. He also said that he has gay friends, goes to WNBA games, went to the Madonna concert and plans to attend the Gay Games in Chicago. 'I called that of this man [Mariotti]', he said. 'I'm not trying to hurt anybody [else].'

Couch wasn't buying Guillen's justification ... A day later, Guillen sort of apologized: 'I shouldn't have mentioned the name that was mentioned. A lot of people's feelings were hurt, and I didn't mean it that way', Guillen explained. 'I apologize, but I wasn't talking about those people.'

'Those people'? How lovely.

Analysis: Couch is right and baseball needs to take action against Guillen. Claiming a cultural exemption doesn't wash. If I went to Venezuela and used language that slurred a group, then tried to claim it was OK by my country's standards, I'd be labeled an Ugly American.

Guillen uses homophobic language, then tries to cop out with the old 'some of my best friends are gay' crap we hear from bigots all the time. And his Madonna Defense is especially lame. Words matter and Guillen should be held accountable. Winning a World Series shouldn't provide cover.

(Our Sports 2006a)

In evaluating Guillén's apology, Out Sports frames it as unacceptable and insincere in several ways. First, the analysis refuses to characterize Guillén's text as an apology, but instead qualifies that Guillén 'sort of apologized'. Further, Out Sports dismisses Guillén's explanations as an attempt to 'cop out' and equates the explanation with 'crap'. In addition, Out Sports equates Guillén explanation with the discourse of bigots, thus suggesting that Guillén is a bigot, which would serve to seriously undermine his sincerity. In sum, insofar as it represents some members of the LGBT community, Out Sports rejects Guillén's apology. This rejection is echoed in the majority of discussion board comments from Out Sports readers. The Out Sports analysis and majority of the discussion board comments clearly evaluate the use of fag as inappropriate and offensive and the apology insincere. In contrast, some of those who commented on the Out Sports discussion board both judge the apology as sincere and acceptable and also classify the public use of $f a g$ as something less than a slur or hate speech. Four examples of these dissenting evaluations are presented as $(2-5)$ below: 
(2) 'His sensitivity is certainly in need of raising, but how many men use that word in anger? Lots. I have.'

(Bill W)

(3) 'I think he used the word in a fit of anger, without any malicious intent toward gays ... I think we should give him the benefit of the doubt on this. We all say things we shouldn't in a fit of anger.'

(Thomas)

(4) 'I've heard that word used in many locker rooms. Some use it to bully others into playing more aggressively. Some use it to vent anger and frustration on opposing players who kicked our ass ... Guillen is product of that locker room jock culture, and that culture is still alive and well inside his psyche.'

(Thomas)

(5) 'I have a feeling $90 \%$ of baseball players have called someone a fag at one time or another. Ozzie just said it to the wrong crowd. That makes him stupid, but is he really more of a bigot than many, many, many other jocks?'

(bridgeportjake)

These members of the LGBT community ${ }^{7}$ articulate a more accepting stance to Guillén's use of fag, providing two explanations that Guillén did not articulate in his apology: first, that the acceptability of a word may vary from context to context and that the use of fag in the context of (professional) sports may be more acceptable than in other contexts; and second, that the speaker's state of mind or disposition might affect her/his ability to choose the most appropriate word and that the manager's anger might have contributed to his use of an offensive word. These comments echo Anderson (2005: 91), who found that the word fag was pervasive in sports culture and that 'homonegative discourse is a habit for most team sport athletes, whether they intend to cause harm through this discourse or not'. While there is not sufficient space to go into reactions and comments on other sports websites, it is worthwhile to add here that on many of the non-corporate sites, such as Deadspin (deadspin.com) for example, the use of the word fag is pervasive in discussion board posts on the incident, and not for its metalinguistic function.

While many people in and out of the LGBT community called for Guillén to be fired or suspended, the consequences of the incident for Guillén included a monetary fine of an undisclosed amount and mandatory sensitivity training, both imposed by Major League Baseball. Guillén was allowed to manage the American League team in the Major League Baseball All-Star game, a high-profile honor given to the manager of the reigning League Champions, the following month in July 2006. 


\subsection{Case 2: Governor Bill Richardson, politician}

A second case of the use of what might be considered a homophobic slur in public discourse occurred a few months before the Guillén incident, in March 2006. The case involves New Mexico Governor Bill Richardson, a Mexican-American politician who has served as a Congressman, a Secretary in President Bill Clinton's cabinet, and as the U.S. Ambassador to the United Nations.

Stage one of the public apology incident, the transgression of the sociocultural order, took place when Governor Richardson used the Spanish term maricón in an interview with the controversial talk radio host Don Imus on his syndicated show that was simulcast on the cable television network MSNBC. The exchange between Imus (I) and Governor Richardson $(\mathrm{R})$ is reproduced below:

(6)

$01 \mathrm{I}$ : (and finally) I uh ((clears throat)) Governor Richardson I apologize for this but

02 uh Bernard's been claiming you're not really Hispanic so that you're just

03 claiming that so

04 R: ((laughs))

$05 \mathrm{I}$ : for some advantage or something so uh you can just answer this yes or no uh 06 and and and and we'll that this will answer that question would you agree that

07 Bernard is a maricón? [faggot] uh:::

08 R: yo creo que Bernardo sí es un maricón si él dice que yo no soy

09 hispano ['I think that Bernardo yes is a faggot if he says that I am not Hispanic']

$10 \mathrm{I}:$ ((laughs)) thanks Governor

$11 \mathrm{R}$ : was that good enough or what?

$12 \mathrm{I}$ : ((laughs)) that's good enough for me

$13 \mathrm{R}$ : all right

14 I: Governor Bill Richardson here on the broadcast ...

There are perhaps two features of this interaction that are most notable. First, Imus hesitates and hedges repeatedly, from the throat-clearing (line 01) to the repeated use of 'uh' (lines 01, 02, and 03), from the repetition of 'and' (line 06) to his pre-emptive apology, 'I apologize for this' (line 01). Imus's dysfluency as he poses the question to Richardson, could be interpreted as a recognition of both the face-threatening accusation he is voicing (i.e., that Richardson is falsely claiming a Latino ethnicity in order to court voters or receive some other advantage as a presidential candidate) and the extremely awkward position that he is putting his interviewee in (i.e., the need to prove his ethnicity by participating in what might be considered a homophobic taunt). Second, but equally notable, is that although Imus is halting and quite dysfluent, Richardson seems almost eager to participate, to the point 
that he even overlaps Imus's question in order to answer it (line 08). Richardson code-switches to Spanish in order to answer, and, even though Imus had specifically prompted that he only needed to say yes or $n o$, he uses the word maricón while participating in this joke in order to prove his Hispanic/Latino authenticity.

Unlike in the Guillén case above, in this case the second stage of the public apology incident - accusation of wrong-doing - was significantly delayed. Although Richardson is reported to have apologized immediately after the radio appearance in a private phone call to the Executive Director of Equality New Mexico, an LGBT group in the governor's state (Woodard Mederazo 2007), he did not apologize publicly until over a year later after an accusation of wrong-doing was made by LGBT blogger Citizen Crain, who accused Richardson of hypocrisy for criticizing right-wing Ann Coulter's use of the word 'faggot' (to describe Democratic candidate John Edwards) at a Human Rights Campaign gala event while he was on the campaign trail. In July 2007, Richardson apologized in an interview with reporter Scott Sonner from the Associated Press (AP), all of the published excerpts of which are reprinted as below: ${ }^{8}$

(7)

01 I would never knowingly say or do anything to hurt the GLBT community - a

02 community that I have worked hard for and supported my entire career.

03 In the Spanish I grew up speaking, the term means simply 'gay', not positive or negative.

04 It has been brought to my attention that the word also has a hurtful or derogatory

05 connotation, which was never my intent. If I offended anybody, I'm sorry.

06 My record on GLBT issues speaks for itself. I have certainly done more to help and

07 support the GLBT community than any other presidential candidate, and more than most

08 other politicians. The timing of this smacks of politics - it comes as I am gaining

09 momentum and moving up in the polls.

10 My record is the strongest among the presidential candidates on gay rights issues and I'm 11 puzzled by the timing of this. When it happened a year ago, nobody seemed to think it

12 was terribly important. Now it surfaces. It's probably a sign from other campaigns that

13 they are little worried about me. It was a playful exchange between me and Don Imus

14 that was not intended to demean anybody, but if I offended anybody, I apologize.

Like the Guillén case above, the Richardson case is somewhat complicated by the question of who is the wronged party, although significantly less so than in the previous case. The direct target of Richardson's slur, Bernard McGuirk, the executive producer of Imus' radio show, could be said in some sense to be the wronged party. Unlike Mariotti, however, Bernardo did not orient in any way to Richardson's use of maricón as an insult, and he in no way we know of demanded an apology. Instead, it appears, that he was very much in on the joke and, we can assume, thus oriented to Richardson's remark. Therefore, 
while McGuirk was the direct target of Richardon's use of maricón, members of the LGBT community and not McGuirk could be said to be the wronged party in the situation. Accordingly, solely the LGBT community and not McGuirk will be viewed as the wronged party in the analysis of the apology that follows.

Like Guillén's, Richardson's apology contains both prototypical and non-prototypical apology features according to Jeffries' model. In the first cluster of features related to the apology IFID, Richardson's apology is prototypical. He uses the first person, present tense expression of regret 'I'm sorry' (line 05). In addition, he also uses the alternative performative 'I apologize' (line 14).

The second cluster of features related to the discourse context of the apology, however, is less prototypical. Because the apology is only available through a published Associated Press interview, it is not possible to say unequivocally that Richardson makes no offers of reparation or expressions of concern following the apology, but this prototypical feature was not part of the published apology. In addition to the lack of reparation/concern, the following text contains no explicit taking of responsibility. Richardson does, however, employ the alternative strategy of giving explanations to mitigate his offense. Richardson's explanations revolve around three key points: first, Richardson asserts his ignorance of the meaning of the word maricón, 'In the Spanish I grew up speaking, the term means simply "gay", not positive or negative' (line 03); second that no offense was intended, 'I would never knowingly say or do anything to hurt the GLBT community' (line 01), 'the word also has a hurtful or derogatory connotation, which was never my intent' (lines 04-05), and 'that was not intended to demean anybody' (line 14); and finally, Richardson claims that his record on LGBT issues is exemplary, 'a community that I have worked hard for and supported my entire career' (lines 01-02), 'My record on GLBT issues speaks for itself. I have certainly done more to help and support the GLBT community than any other presidential candidate, and more than most other politicians' (lines 06-08) and 'My record is the strongest among the presidential candidates on gay rights issues' (line 10). In addition to these explanations, the following text of Richardson's apology also includes a feature not included in Jeffries (2007), namely questioning the motives and sincerity of those making demands for his apology (lines 10-13). In the text that is available there is no explicit claim of responsibility, but neither is there an attempt to shift blame to another party.

Regarding the third cluster of features (level, timing, sincerity, addressee, and impetus) Richardson's apology is again less than prototypical. While the level of the apology addresses the main/sole signifi- 
cant wrong between the speaker and the wronged party, the apology in July 2007 takes place over a year after the original incident in March 2006 and the addressee is a news reporter/interviewer rather than the wronged party. The impetus is also least prototypical, as the apology was demanded by LGBT bloggers and advocacy groups and also, we can imagine although we have no way of knowing, prompted in some way by questions from the interviewer. Given the IFIDs, it is clear that Richardson intends this as an apology, and given his status as a Governor and presidential candidate, it can be inferred that there exists a differential of power between Richardson and the LGBT community that goes beyond the transgression in question. There is no indication that Richardson does not agree with the best interests of the aggrieved party. The subjective feature of sincerity will be addressed below, as will acceptability/outcome.

Analysis of the incident on the LGBT blog that broke the story, Citizen Crain evaluates both Richardson's use of maricón and his apology:

At a more fundamental level, Richardson's wavering explanations about 'maricón' strain credulity. If 'maricón' means 'simply gay, not positive or negative', then why in the world would Don Imus suggest his staffer was 'simply gay, not positive or negative' for thinking Richardson isn't truly Latino? Why would Richardson agree? It's also hard to believe Richardson has 'since learned' that 'maricón' is offensive. Spanish-language dictionaries refer to it as a derogatory epithet, and I've yet to talk to a gay Latino who disagreed or had heard otherwise. The Gay \& Lesbian Alliance Against Defamation has for years taken Spanish-language media to task for using 'maricón.' In one press release, GLAAD referred to 'maricón' as a 'derogatory slur' that is 'vulgar, defamatory and unacceptable'. (Crain 2007)

Crain clearly judges maricón to be a slur, and he cites both Spanish dictionary definitions of the word as 'a derogatory epithet' and the Gay \& Lesbian Alliance Against Defamation (GLAAD) definition of the term as a 'derogatory slur,' as well as unnamed gay Latinos. Most fundamentally, Crain's evaluation of the apology questions Richardson's sincerity, arguing that his explanations 'strain credulity' and that his recent understanding that maricón might be offensive is 'hard to believe'. Crain's evaluation indicates that he does not view Richardson's apology as sincere or acceptable.

A popular Latina/o blog 'Vivir Latino' also featured an analysis of the incident and the apology (emphasis original): 
Richardson has loudly been proclaiming himself as THE Latino Presidential candidate but with language like that does he represent all Latinos? And why did it take over a year for this to make media waves? Did he think he could get away with it because he was speaking Spanish? Did he think that he could rely on the machismo and homophobia oh so present in the Latino community that the Spanish speakers wouldn't care? ... And yes while the question was clearly a set up, a politician with Richardson's experience could have and should have deflected it. What if it had been the ' $n$ ' word. Wouldn't he have been attacked at last month's debate? ... Richardson has claimed that he thought the word meant effeminate, not the ' $\mathrm{f}$ ' word, which in my opinion is a load of bs that I'm not shoveling. So while I may have declared Richardson 'gay friendly' before, now I wonder if he's friendly to gays, Latinos, and obviously gay Latinos.

(Mederazo Woodward 2007)

Like Crain, Mederazo Woodward also characterizes maricón as a slur, equivalent to what she calls 'the "f" word.' Also like Crain, Mederazo Woodward questions Richardson's explanations, which she characterizes and 'a load of bs'. She asserts that Richardson's use of maricón might indicate a lack of sincerity in his support of the LGBT community, which leads her to question his sincerity in his support of Latinos as well.

The comments from the on-line discussion of the Vivir Latino and Citizen Crain analyses indicate a range of reactions to Richardson's use of maricón within the (presumed) LGBT and (presumed) Latina/ o communities. For some, maricón and fag are not equivalent, and the fact that maricón means jerk, wimp, or sissy but not fag(got) makes the Governor's comments not offensive. For others, there is no question that maricón is equivalent to fag(got) and as such should be considered a homophobic slur. Many felt that, while it was a mistake, it should not outweigh Richardson's long record of support of the LGBT community, while still others felt that Richardson's use of maricón is not acceptable, is offensive and calls into question his support of Latinos and the LGBT community.

In early 2008, Richardson withdrew from the race for the Democratic nomination for the presidential election after coming in a distant fourth to Barack Obama, John Edwards, and Hillary Rodham Clinton in two important early state contests, and he then endorsed candidate Barack Obama. He finished his term as New Mexico Governor at the end of 2010. 


\section{Discussion}

The topic of impoliteness in bilingual or cross-cultural contexts is one that merits further research beyond the second language classroom where much of it is focused. In particular the use of highly charged terms, such as those that might be considered racist, sexist, or homophobic, by native or highly proficient bilinguals and their evaluation by participants has received little attention in the field. The relational work of bilingual participants in interaction merits further attention, not only because bilingualism and multilingualism are widespread phenomena experienced by the majority of the world's population, but also because, particularly in the case of members of ethnolinguistic minorities in predominantly monolingual nations, bilinguals are often held to a higher standard and criticized for what are seen to be their linguistic failings by monolinguals in either language (Zentella 1997a, 1997b).

This is especially salient in the Guillén case, where a person who is teased and taunted for his lack of proficiency in English is rejected when he attempts to use this lack of proficiency to explain his use of what is judged to be an inappropriate and unacceptable homophobic slur. The questionable or suspect status of bilinguals, especially Latinos in the U. S., also surfaces in the Richardson case, in which lack of Spanish proficiency, or more specifically (ignorance of) putative language variation is used to explain the use of what might be considered a homophobic slur.

The two cases examined above indicate some degree of discursive and ideological struggle over the appropriateness of the terms fag and maricón by bilingual Latinos in public discourse in the United States. First, there appears to be some question as to the status of maricón as a homophobic slur equivalent of fag (got) in English. Second, the examination of the discursive struggle over the appropriateness of fag and maricón in public discourse seems to reveal that both the word used (and the language of the word used), as well as the context and the speaker's identity impact the public's evaluation. Finally, it is clear that fag(got) is broadly considered to be a slur, although this does not mean that it is not widely used and accepted in certain contexts (i.e., sports culture); it is generally accepted that maricón is a translation of fag $(g o t)$ and, therefore, also a slur, although some leeway is given to dialectal variation or misunderstanding of this status. Unlike the acrossthe-board dismissal of Guillén's linguistic claim that fag meant something different in his home country, Richardson's linguistic claim received some support. Furthermore, Richardson's track record on support of LGBT issues was viewed by many to mitigate the question of intention, while Guillén's track record of being 'politically incorrect' 
and specifically engaging in a prior incident considered homophobic was seen to aggravate the situation and undermine his sincerity. So, Richardson's apology could be seen as more successful than Guillén's, and the use of maricón in public discourse could be said to have been judged as less offensive that the use of fag.

One would expect that the use of homophobic slurs in public discourse in the political arena would not be acceptable for politicians, particularly liberal or progressive candidates who might be expected to be more tolerant. As the case of Richardson indicates, however, this is something that is open to some struggle. When Richardson first used maricón on the Don Imus show, it was brought to the attention of a particular LGBT organization from his home state of New Mexico that decided to not pursue it, publicize it, or demand an apology from the Governor. Perhaps because Governor Richardson's use of homophobic discourse was in Spanish, it was less remarkable to the majority of U. S. viewers/listeners than Guillén's use of $f a g$, which although not recorded or televised, was spoken in English and reported widely by the English language media. Both bloggers considered maricón utterly unacceptable, but many of those who commented on their site articulated a more nuanced position in which a candidate's policy record on a given issue might outweigh their use of what could be considered a slur.

Overall, the posts on the Out Sports website expressed disappointment, anger, and a rejection of the use of fag and of Guillén's apology, and the use of the word was described as unacceptable by the commissioner of the league. A small number of posts on Out Sports, however, argued that, while still not acceptable, Guillén's use of fag is an example of such pervasive homophobia in the world of professional sports that Guillén himself should not be censured for his use of it. Despite this, Guillén's use of fag caused markedly more public scandal than Richardson's use of maricón, despite the fact that it was allegedly offthe-record and not even recorded. It would seem, therefore, that this comparison indicates that the use of what is considered a slur in English trumps the hierarchy one might assume of politics as more restrictive than sports in terms of acceptability of homophobic discourse.

It bears noting that neither target in the two cases is known to be gay, a fact that complicates the straightforward interpretation of the use of fag and maricón as hate speech or discriminatory discourse. Are Guillén's use of fag and Richardson's use of maricón homophobic? And what do the two incidents tell us about the discursive construction of homophobia and masculinity? Pascoe (2005: 330) critiques the argument that the use of $f a g$ as an epithet in adolescent joking is always and only homophobic. Importantly, Pascoe points out that 
'[f]ag' is not necessarily a static identity attached to a particular (homosexual) boy. Fag talk and fag imitations serve as a discourse with which boys discipline themselves and each other through joking relationships. Any boy can temporarily become a fag in a given social space or interaction ... This fluidity of the fag identity is what makes the specter of the fag such a powerful disciplinary mechanism.

The use of $f a g$ as a disciplinary mechanism that in effect polices masculinity describes the first case study. Guillén, a successful baseball manager, angry at a reporter whom he feels constantly criticizes him, his players, and his organization retaliates by attributing the fag label to him in order to assert his own superiority as a real man and discipline the reporter for his transgression. While the LGBT community may feel it necessary to protest the use of the derogatory term and the sports journalists may feel obliged to question the appropriateness of the public use of the slur, sexual identities are irrelevant to this incident. Guillén uses the slur to 'do masculinity' in his clubhouse interaction with the reporters. This performance of masculinity is continued in the apology, in which Guillén further attacks and undermines Mariotti's manhood, saying that he is not a man, challenging him to a face to face interaction, calling him 'afraid' and 'silly'.

In the Richardson case, the situation is somewhat different. To some extent, one could argue that Richardson, too, is 'doing masculinity' in his use of maricón in that he has been challenged by the radio host, and he must be a man by responding to that challenge. For Richardson, however, the use of maricón as an insult term or taunt was a resource for resisting or countering racist discourse. Imus' assertion (via his producer McGuirk) that Richardson was not Latino but only claiming to be for an alleged electoral advantage introduces a problematic, racist discourse. Richardson engages in the use of Spanish in an effort to prove his Latino identity, a move that both authenticates the languageidentity link between Spanish and Latina/o identity, and reifies the stereotypical machismo and homophobia of an essentialized 'Latino culture' in order to resist Imus' racist discourse. This intersection of antiracism and heterosexism is of great interest because, among other things, it calls into question the place of/for ethnolinguistic minorities like US Latinos who are also LGBT given the essentializing nature of the discourse in which Latinos are constructed as heterosexual and lesbians and gay men are constructed as white. A simple analysis of the use of fag or maricón as discriminatory discourse would miss the richness and complexity of the on-the-ground struggle over their use, and how this struggle is impacted by the broader social context of eth- 
nicity and sexual identity among bilinguals and monolinguals, Anglos and Latinas/os and LGBT, and heterosexual participants in interaction.

\author{
University of New Hampshire
}

\title{
Notes
}

* I would like to thank the following colleagues for valuable feedback on an earlier version of this analysis: Lori Hopkins, Mary Rhiel, Amy Boylan, Paula Salvio, and Roz Chavda. I also thank Carmen García, who gave a helpful and challenging critique at the earliest presentation of the analysis, and two anonymous reviewers who provided detailed and useful feedback. All remaining weaknesses are my own.

1. 'Latinas/os' is an abbreviation of 'Latinas and Latinos', an expression that aims to include both male and female members of the ethnic group.

2. I have chosen to use an accent here, although his name appears most frequently in the U.S. without one, because an accent is used in the Spanish-language versions of official Chicago White Sox publication and on-line.

3. Nuessel (1982: 346) defines eye dialect as 'typographical alterations ... used in direct speech such as monologue ... [to] represent casual or colloquial speech which often characterizes an individual as belonging to the lower socio-economic stratum of society (thieves, prostitutes, pimps, beggars, etc.), a particular minority group (blacks, native Americans gypsies, etc.), other identifiable division (foreigners, peasants, etc.) and gender'.

4. It should be noted at the outset that Mariotti, a controversial and not particularly well-liked figure in Chicago sports reporting, is not (known to be) gay. Similarly, Bernard the target of the homophobic slur in the second case is not (known to be) gay.

5. It should be noted that there is a serious weakness in the data of Guillén's apology. The recording seems to have started after a question had been asked, and it seems to end before the end of the question and answer session. It is therefore unknown whether this recording represents all of Guillén's remarks about the incident during that informal Q\&A.

6. LGBT is an abbreviation of lesbian, gay, bisexual, and transgender, a term meant to be inclusive of the spectrum of sexual identities and gender identifications and expressions also covered by the global term 'queer'. The order of the first two letters in this abbreviation is sometimes reversed to GLBT, such as in the apology statement from Governor Bill Richardson in the second case study.

7. It is important to note that one in fact has no way of knowing the sexual identities or gender identities/expressions of those who comment on Out Sports, and therefore it is only a presumption that all those who comment, regardless of the opinion expressed, are LGBT. This is meant as a general caveat and not to relate specifically to those who defend Guillén and/or accept his apology.

8. At the outset, it is necessary to flag a serious weakness in the available data of Richardson's apology: it is only available via published news reports of an Associated Press interview. The complete text of the interview is not available, and we are only able to analyze the direct quotes published and attributed to Richardson. 


\section{References}

Alexander, Lisa Doris. 2006. Race on first, class on second, gender on third, and sexuality up to bat: Intersectionality and power in Major League Baseball, 1995-2005. Bowling Green, OH: Bowling Green State University dissertation.

Anderson, Eric. 2005. In the game: Gay athletes and the cult of masculinity. Albany NY: SUNY Press.

Baker, Mona, Gill Francis \& Elena Tognini-Bonelli (eds.). 1993 Text and technology. Philadelphia/Amsterdam: John Benjamins.

Blum-Kulka, Shoshana, Juliane House \& Gabriele Kaspar (eds.). 1989. Cross-cultural pragmatics: Requests and apologies. Norwood, NJ: Ablex Publishing.

Bousfield, Derek. 2008. Impoliteness in interaction. Amsterdam/New York: John Benjamins.

Cohen, Andrew D. \& Elite Olshtain. 1981. Developing a measure of sociocultural competence: The case of apology. Language Learning 31(1). 113-134.

Couch, Greg. 2006. Chicago Sun-Times 21 June (accessed 3 March 2008).

Crain, Chris. 2007. Bill Richardson's 'maricón moment'. Citizen Crain: an independent gay blog $10 \mathrm{July}$ http://citizenchris.typepad.com/citizenchris/2007/07/billrichardson.html (accessed 9 February 2010).

Cubillo, Igor. 1998. Los 'gays' vascos piden el secuestro del disco del conjunto mexicano Molotov: EGHAM presenta una denuncia judicial por homofobia. ElPaís.com 2 October http://www.elpais.com/articulo/pais/vasco/MOLOTOV_/ MUSICA/gays/vascos/piden/secuestro/disco/conjunto/mexicano/Molotov/ elpepuesppvs/19981002elpvas_22/Tes (accessed 16 December 2010).

Culpeper, Jonathan. 1996. Towards an anatomy of impoliteness. Journal of Pragmatics 25(3). 349-367.

Darder, Antonio, Rodolfo D. Torres \& Henry Gutiérrez (eds.). 1997. Latinos and education: A critical reader. New York: Routledge.

El Comercio. 2010. 'Maricón es el que maltrata a una mujer': el eslogan de una polémica campaña en Chile. Elcomercio.com 29 October 2010 http:// elcomercio.pe/mundo/661193/noticia-maricon-que-maltrata-mujer-esloganpolemica-campana-chile (accessed 17 December 2010).

ESPN. 2006. Guillen fined, ordered to take sensitivity training for slur. Espn.com 23 June http://sports.espn.go.com/mlb/news/story?id=2496753 (accessed 1 July 2009).

Goffman, Erving. 1971. Relations in public: Microstudies of the public order. New York: Basic Books.

Harris, Sandra, Karen Grainger \& Louise Mullany. 2006. The pragmatics of political apologies. Discourse \& Society 17(6). 715-737.

Hayes, Neil. 2009. Lou, Ozzie too frank for players. Chicago Sun-Times 1 July http:// www. suntimes.com/sports/hayes/1646478,CST-SPT-neil01.article (accessed 1 July 2009).

Hearit, Keith Michael. 2005. Crisis management by apology: Corporate responses to allegations of wrongdoing. Mahwah, NJ: Lawrence Erlbaum.

Henderson, Anita. 2003. What's in a slur? American Speech 78(1). 52-74.

Jeffries, Lesley. 2007. Journalistic constructions of Blair's 'apology' for the intelligence leading to the Iraq war. In Sally Johnson \& Astrid Ensslin (eds.), Language in the media: Representations, identities, ideologies, 48-69. London/New York: Continuum.

Johnson, Sally \& Astrid Ensslin (eds.). 2007. Language in the media: Representations, identities, ideologies. London/New York: Continuum.

King, Ruth \& Sandra Clarke. 2002. Contesting meaning: Newfie and the politics of ethnic labelling. Journal of Sociolinguistics 6(4). 537-556. 
Locher, Miriam. 2004. Power and politeness in action: Disagreements in oral communication. Berlin: Mouton de Gruyter.

Locher, Miriam \& Richard Watts. 2005. Politeness theory and relational work. Journal of Politeness Research 1. 9-33.

Louw, Bill. 1993. Irony in the text or insincerity in the writer? The diagnostic potential of semantic prosodies. In Mona Baker, Gill Francis \& Elena Tognini-Bonelli (eds.), Text and technology, 157-176. Philadelphia/Amsterdam: John Benjamins.

Matsuda, Mari J., Charles R. Lawrence, Richard Delgado \& Kimberle Williams Crenshaw. 1993. Words that wound: Critical race theory, assaultive speech, and the first amendment. Boulder, CO: Westview Press.

Mbaye, Abdoulaye. 2005. The pragmatics of public apologies. LLC Review 5(1). $32-$ 39.

Mills, Sara. 2003. Gender and politeness. Cambridge: Cambridge University Press.

Nuessel, Frank H., Jr. 1982. Eye dialect in Spanish: Some pedagogical implications. Hispania 65(3). 346-351.

Olshtain, Elite \& Andrew D. Cohen. 1983. Apology: A speech-act set. In Nessa Wolfson \& Elliot Judd (eds.), Sociolinguistics and acquisition, 18-36. Rowley, MA: Newbury House.

Out Sports. 2006a. Ozzie Guillen Chicago White Sox manger June 20, 2006 Analysis. Outsports.com. http://www.outsports.com/antigay/antigayrockerslist.htm (accessed 9 February 2010).

Out Sports. 2006b. Ozzie Guillen, Homophobe (Discussion Board). Outsports.com http://www.outsports.com/forums/index.php?showtopic=758\&hl=Guillen (accessed 9 February 2010).

Pascoe, C.J. 2005. 'Dude, you're a fag': Adolescent masculinity and the fag discourse. Sexualities 8(3). 329-346.

Reilly, Rick. 2006. The magical and mysterious Oz. Sports Illustrated 24 April http:// vault.sportsillustrated.cnn.com/vault/article/magazine/MAG1110829/1/ index.htm (accessed 1 July 2009).

Sports Business Daily. 2006. Closing bell. SportsBusinessDaily.com http:// www.sportsbusinessdaily.com/article/103677 (accessed 1 July 2009).

Suszczynska, Malgorzata. 1999. Apologizing in English, Polish and Hungarian: Different languages, different strategies. Journal of Pragmatics 31. 1053-1065.

Watts, Richard. 2003. Politeness. Cambridge: Cambridge University Press.

Watts, Richard. 2008. Rudeness, conceptual blending theory and relational work. Journal of Politeness Research 4. 289-317.

Wolfson, Nessa \& Elliot Judd (eds.). 1983. Sociolinguistics and acquisition. Rowley, MA: Newbury House.

Woodward Mederazo, Jennifer. 2007. Bill Richardson: not such a Latino/gay friendly candidate. Vivir Latino 11 July http://vivirlatino.com/2007/07/11/bill-richardsonnot-such-a-latinogay-friendly-candidate.php (accessed 9 February 2010).

Zentella, Ana Celia. 1997a. Growing up bilingual. Malden, MA/Oxford: Blackwell.

Zentella, Ana Celia. 1997b. Returned migration, language and identity: Puerto Rican bilinguals in dos worlds/two mundos. In Antonio Darder, Rodolfo D. Torres \& Henry Gutiérrez (eds.), Latinos and education: A critical reader, 302-318. New York: Routledge.

Zwicky, Arnold. 2006. Avoiding the other f-word. Language Log 4 July http:// 158.130.17.5/ myl/ languagelog/archives/003319.html (accessed 1 July 2009).

Holly R. Cashman is an Assistant Professor of Spanish in the Department of Languages, Literatures \& Cultures at the University of New Hampshire, USA. Her research focuses on Spanish in the U. S., bilingual conversation, impoliteness and queer 
linguistics. Her work has been published in journals including: Multilingua, Journal of Politeness Research, Journal of Multilingual and Multicultural Development and Spanish in Context. She has also contributed chapters to The Blackwell guide to research methods in bilingualism and multilingualism (Li Wei \& Melissa G. Moyer, eds.), Impoliteness in language (Derek Bousfield \& Miriam Locher, eds.) and Research on politeness in the Spanish speaking world (María Elena Placencia \& Carmen García, eds.).

Adress for correspondence: Dept. of Languages, Literatures \& Cultures, Murkland Hall 210G, University of New Hampshire, Durham, NH 03824, USA

e-mail: holly.cashman@unh.edu 

Copyright of Multilingua is the property of De Gruyter and its content may not be copied or emailed to multiple sites or posted to a listserv without the copyright holder's express written permission. However, users may print, download, or email articles for individual use. 